\title{
3-Phosphoglycerate dehydrogenase deficiency: an inborn error of serine biosynthesis
}

\author{
J Jaeken, M Detheux, L Van Maldergem, M Foulon, H Carchon, E Van Schaftingen
}

\begin{abstract}
Serine concentrations were markedly decreased in the cerebrospinal fluid of two brothers with congenital microcephaly, profound psychomotor retardation, hypertonia, epilepsy, growth retardation, and hypogonadism. The youngest boy also had congenital bilateral cataract. Magnetic resonance imaging of the brain showed evidence of dysmyelination. Plasma serine as well as plasma and cerebrospinal fluid glycine concentrations were also decreased but to a lesser extent. Treatment with oral serine in the youngest patient significantly increased cerebrospinal fluid serine and abolished the convulsions. In fibroblasts of both patients, a decreased activity was demonstrated of 3-phosphoglycerate dehydrogenase, the first step of serine biosynthesis ( $22 \%$ and $13 \%$ of the mean control value). This is an unusual disorder as the great majority of aminoacidopathies are catabolic defects. It is a severe but potentially treatable inborn error of metabolism that has not been previously reported in man.

(Arch Dis Child 1996;74:542-545)
\end{abstract}

Keywords: cerebrospinal fluid, 3-phosphoglycerate dehydrogenase, serine.

Serine is a key amino acid as it is not only a building block for protein synthesis but also a precursor for the synthesis of a number of compounds including glycine, cysteine, serine phospholipids, sphingomyelins, and cerebrosides. It is also a major source of methylenetetrahydrofolate and of other one carbon donors that are required for the synthesis of purines and of thymidine. ${ }^{12}$ Serine is a non-essential amino acid, synthesised de novo from a glycolytic intermediate, 3-phosphoglycerate. As shown in fig 1, the latter is converted to serine through the successive action of 3-phosphoglycerate dehydrogenase (EC 1.1.1.95 ), 3-phosphoserine aminotransferase (EC 2.6.1.52), and 3-phosphoserine phosphatase (EC 3.1.3.3). ${ }^{3}$ This pathway is present in several tissues including brain, kidney, testes and liver, and is also active in proliferating cells. ${ }^{4-7}$ Serine can also be synthesised from glycine by reversal of the reaction catalysed by serine hydroxymethyltransferase.

During a systematic amino acid analysis of cerebrospinal fluid and plasma in children with psychomotor retardation, we noted decreased concentrations of serine and glycine in two brothers. Further investigation revealed a defect in the synthesis of serine due to 3-phosphoglycerate dehydrogenase deficiency.

\section{Case reports}

The patients, two brothers, were from a Turkish family. The parents were first cousins. They were healthy and had a normal height and head circumference. Their first child was healthy and showed normal plasma amino acid concentrations. The third child (case 1) was born after a normal term pregnancy with weight of $2130 \mathrm{~g}$ ( 3 rd centile $2600 \mathrm{~g}$ ), length $43 \mathrm{~cm}$ (3rd centile $47 \mathrm{~cm}$ ), and head circumference $29 \mathrm{~cm}$ (3rd centile $33 \mathrm{~cm}$ ). At the age of 3.5 months he was admitted for investigation of congenital bilateral cataracts and feeding difficulties. Weight was $3700 \mathrm{~g}$ ( 3 rd centile $5100 \mathrm{~g}$ ), length 50.5 $\mathrm{cm}$ ( $3 \mathrm{rd}$ centile $58 \mathrm{~cm}$ ), and head circumference $34.2 \mathrm{~cm}$ ( $3 \mathrm{rd}$ centile $39 \mathrm{~cm}$ ). He was severely retarded, hypertonic, and hyperexcitable. Tendon reflexes were normal. There was adduction of the thumbs and pes calcaneovalgus. He also had small testes. At the age of 1 year he developed epilepsy. Laboratory investigation could not demonstrate intrauterine infection. Chromosomal analysis was normal. Plasma amino acid analysis by ion exchange chromatography and fluorescence detection revealed low fasting concentrations of serine ( 29 and 55 ; normal range for age $70-187 \mu \mathrm{mol} / \mathrm{l}$ ) and low to normal fasting concentrations of glycine (77 and $97 ; 80-341 \mu \mathrm{mol} / \mathrm{l})$. In the cerebrospinal fluid, protein was normal, serine was severely decreased $(6 ; 35-80 \mu \mathrm{mol} / \mathrm{l})$, and glycine was also decreased but less so $(2.8 ; 3.6-$ $9.0 \mu \mathrm{mol} / \mathrm{l})$. Organic acids in urine were normal. Oral treatment with serine significantly increased cerebrospinal fluid serine concentrations in a dose dependent way: the cerebrospinal fluid serine was $15 \mu \mathrm{mol} / 1$ after one week at $100 \mathrm{mg} / \mathrm{kg} /$ day (in three divided doses) and 20 $\mu \mathrm{mol} / \mathrm{l}$ after one week at $200 \mathrm{mg} / \mathrm{kg} /$ day. Under the latter dose the convulsions stopped after one week. Further studies could not be performed due to lack of cooperation of the parents. Electroencephalography showed epileptic activity, and magnetic resonance imaging of the brain showed cortical and subcortical hypotrophy as well as evidence of dysmyelination.

The second child (case 2) showed a similar clinical picture but no cataracts. Birth weight was 3040 g. Epilepsy developed after the age of 2 months. At 7 years, weight was $13 \mathrm{~kg}$ (3rd centile $18 \mathrm{~kg}$ ), length $104 \mathrm{~cm}$ (3rd centile 110 $\mathrm{cm}$ ), and head circumference $42.2 \mathrm{~cm}$ (3rd centile $49 \mathrm{~cm}$ ). Psychomotor development was nearly absent. He had a flat occiput, large ears, 


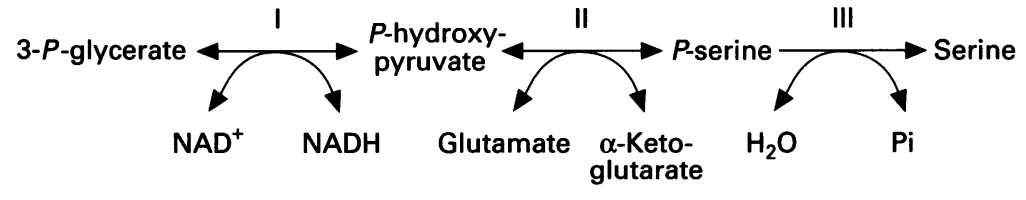

Figure 1 Pathway of de novo serine synthesis. I: 3-Phosphoglycerate dehydrogenase; II:3-phosphohydroxypyruvate transaminase; III: 3-phosphoserine phosphatase (Pi=inorganic phosphate). of polyethyleneglycol- 6000 was then added per $\mathrm{ml}$ of the resulting supernatant, which was mixed and centrifuged as above. The pellet was resuspended in a $25 \mathrm{mM}$ TRIS-hydrochloric acid $(\mathrm{HCl}), \mathrm{pH} 8.5$ buffer containing $10 \mathrm{mM}$ $\mathrm{MgCl}_{2}, 1 \mathrm{mM} \mathrm{DTT}$, and $20 \mathrm{mM} \mathrm{NaCl}$, and applied onto a $40 \mathrm{~cm}^{3}$ column of DEAESepharose Fast-Flow. The retained proteins were eluted with a $20-500 \mathrm{mM} \mathrm{NaCl}$ gradient prepared in $200 \mathrm{ml}$ of the same buffer. 3-Phosphoserine phosphatase came out as a single peak at a sodium concentration of 100 $\mathrm{mM}$. Its specific activity amounted to 40 $\mathrm{mU} / \mathrm{mg}$ of protein corresponding to an 80 -fold purification with a yield of $30 \%$.

PREPARATION OF $\left[{ }^{14} \mathrm{C}\right]$ 3-PHOSPHOSERINE $\left[{ }^{14} \mathrm{C}\right]$ 3-phosphoserine was synthesised by the exchange reaction catalysed by 3-phosphoserine phosphatase. The reaction mixture ( 3 ml) contained $500 \mu \mathrm{M}$ 3-phosphoserine, 80 $\mu \mathrm{M}$ serine, $12.5 \mu \mathrm{Ci}$ of $\left[{ }^{14} \mathrm{C}\right]$ serine, $10 \mathrm{mM}$ $\mathrm{MgCl}_{2}, 4 \mathrm{M}$ urea (to promote the exchange reaction ${ }^{8}$ ), and $12 \mathrm{mU}$ of 3-phosphoserine phosphatase. After a one hour incubation, the reaction was stopped by addition of $100 \mu \mathrm{l}$ of $10 \%$ perchloride acid $\left(\mathrm{HClO}_{4}\right)$. The reaction mixture was neutralised with $3 \mathrm{M}$ potassium carbonate and centrifuged, and the supernatant was diluted to $20 \mathrm{ml}$ with cold water and applied onto a $40 \mathrm{~cm}^{3}$ column of DEAESepharose Fast-Flow. A NaCl gradient (0-500 $\mathrm{mM}$ in $150 \mathrm{ml}$ of $25 \mathrm{mM}$ HEPES, $\mathrm{pH} 7.1$ ) was applied to elute $\left[{ }^{14} \mathrm{C}\right] 3$-phosphoserine.

Fibroblasts (passage 3-11) were cultured in Dulbecco's modified eagle medium supplemented with $10 \%$ fetal calf serum, $1 \mathrm{mM}$ sodium pyruvate, GlutaMAX I, 100U/ml penicillin, and $100 \mu \mathrm{g} / \mathrm{ml}$ streptomycin. Attached cells were released after washing with magnesium and calcium $\left(\mathrm{Mg}^{2+} / \mathrm{Ca}^{2+}\right)$ - free phosphate buffered saline by brief (3-5 min) exposure to the same medium containing $0.02 \%$ trypsin. Released cells were diluted 10 -fold in the culture medium, sedimented by centrifugation $(1000 \times \mathrm{g}, 10 \mathrm{~min})$ and washed twice in $\mathrm{Mg}^{2+} / \mathrm{Ca}^{2+}$-free phosphate buffered saline. Cell pellets were either disrupted immediately for enzyme assays or stored at $-80^{\circ} \mathrm{C}$ for up to three months without loss of activity. For the preparation of cell extracts, pellets $\left(10^{7}\right.$ cells) were resuspended in $250 \mu \mathrm{l}$ of a medium containing HEPES pH 7.1, $1 \mathrm{mM}$ dithiothreitol (DTT), $50 \mathrm{mM}$ sodium chloride $(\mathrm{NaCl})$, and $10 \mu \mathrm{g} / \mathrm{ml}$ of both leupeptin and antipain. The cells were disrupted by three freeze/thaw cycles and a sample was taken for protein determination.

\section{PARTIAL PURIFICATION OF 3-PHOSPHOSERINE} PHOSPHATASE

The livers of three fed rats were homogenised in three volumes of a buffer containing $25 \mathrm{mM}$ 2-[N-morpholino] ethanesulphonic acid (MES), pH 6.5, $10 \mathrm{mM}$ magnesium chloride $\left(\mathrm{MgCl}_{2}\right), 1 \mathrm{mM}$ DTT, $100 \mathrm{mM} \mathrm{NaCl}$, and 10 $\mu \mathrm{g} / \mathrm{ml}$ of both leupeptin and antipain. The homogenate was heated for $5 \mathrm{~min}$ at $65^{\circ} \mathrm{C}$ and then transferred on ice; $0.1 \mathrm{~g}$ of polyethyleneglycol- 6000 was added per $\mathrm{ml}$ of the heated extract and the resulting preparation was centrifuged for $10 \mathrm{~min}$ at $15000 \times g ; 0.15 \mathrm{~g}$

\section{ENZYME ASSAYS}

3-Phosphoglycerate dehydrogenase was assayed spectrophotometrically in a mixture containing $25 \mathrm{mM}$ HEPES, $\mathrm{pH} 7.1,400 \mathrm{mM}$ potassium chloride $(\mathrm{KCl}), 0.15 \mathrm{mM} \mathrm{NADH}$, $0.1 \mathrm{mM}$ 3-phosphohydroxypyruvate, and 10 $\mu \mathrm{g} / \mathrm{ml}$ lactate dehydrogenase. A high concentration of $\mathrm{KCl}$ was included because salt stimulates the reduction of 3-phosphohydroxypyruvate by this enzyme. ${ }^{9}$ Lactate dehydrogenase was added before the cell extract to eliminate the contaminating hydroxypyruvate present in the substrate by converting it to $\mathrm{L}$-glycerate. ${ }^{10}$

3-Phosphoserine aminotransferase was measured by the formation of $\left[{ }^{14} \mathrm{C}\right]$ 3-phosphohydroxypyruvate from $\left[{ }^{14} \mathrm{C}\right]$ 3-phosphoserine. The reaction mixture $(0.1 \mathrm{ml})$ contained 1 $\mathrm{mM}$ 3-phosphoserine, $12500 \mathrm{cpm} / \mathrm{ml}\left[{ }^{14} \mathrm{C}\right]$ 3-phosphoserine, $10 \mathrm{mM} \alpha$-ketoglutarate, 50 $\mathrm{mM}$ TRIS- $\mathrm{HCl}, \mathrm{pH} 8.0,2.5 \mathrm{mM} \mathrm{NADH}$, as well as $15 \mathrm{mU}$ chicken 3-phosphoglycerate dehydrogenase to pull the reaction towards the formation of 3-phosphoglycerate. The reaction was arrested by addition of one volume of $10 \%$ $\mathrm{HClO}_{4}$ and the mixture was centrifuged for 5 min at $2000 \times g$. The resulting supernatant was brought to $500 \mu \mathrm{l}$ with water and applied onto a Dowex AG 1-X8 column ( $1 \mathrm{~cm}^{3}, \mathrm{Cl}^{-}$form). The column was washed successively with $5 \mathrm{ml}$ of $25 \mathrm{mM} \mathrm{NaCl}, 5 \mathrm{ml}$ of $150 \mathrm{mM} \mathrm{NaCl}$, and $4 \mathrm{ml}$ of $300 \mathrm{mM} \mathrm{NaCl}$ in $10 \mathrm{mM}$ HEPES, $\mathrm{pH}$ 7.1 , to successively elute serine, 3-phosphoserine, and 3-phosphohydroxypyruvate. The fractions were mixed with OptiPhase 2 and counted for radioactivity. 
Table 1 Activities of the enzymes of the serine biosynthesis pathway in fibroblasts in $\mathrm{mU} / \mathrm{mg}$ protein; values are mean (SD). Number of controls or, for patients, number of experiments are shown in square brackets

\begin{tabular}{llll}
\hline & $\begin{array}{l}\text { 3-Phosphoglycerate } \\
\text { dehydrogenase }\end{array}$ & $\begin{array}{l}\text { 3-Phosphoserine } \\
\text { aminotransferase }\end{array}$ & $\begin{array}{l}\text { 3-Phosphoserine } \\
\text { phosphatase }\end{array}$ \\
\hline $\begin{array}{l}\text { Controls } \\
\text { Patients }\end{array}$ & $29.5(2.6)[15]$ & $2.0(0.3)[9]$ & $1.7(0.2)[14]$ \\
Case 1 & $6.6(0.5)[8]$ & $2.6(0.7)[3]$ & $2.0(0.2)[10]$ \\
Case 2 & $3.7(0.6)[9]$ & $2.0(0.3)[4]$ & $1.3(0.1)[8]$
\end{tabular}

3-Phosphoserine phosphatase was measured by the release of $\left[{ }^{14} \mathrm{C}\right]$-serine from $\left[{ }^{14} \mathrm{C}\right]$ 3-phosphoserine. The reaction mixture contained $25 \mathrm{mM}$ MES buffer, $\mathrm{pH} 6.5,1 \mathrm{mM}$ $\mathrm{MgCl}_{2}, 1 \mathrm{mM}$ DTT, $0.1 \mathrm{mM}$ serine, and $12500 \mathrm{cpm}$ radiolabelled 3-phosphoserine in a volume of $0.1 \mathrm{ml}$. The reaction mixture was incubated for $30 \mathrm{~min}$ at $30^{\circ} \mathrm{C}$ and the samples were treated as described above, except that the elution was done with $3 \mathrm{ml} 25 \mathrm{mM} \mathrm{NaCl}$ and $3 \mathrm{ml} 200 \mathrm{mM} \mathrm{NaCl}$.

One unit of enzyme is the amount which catalyses the conversion of $1 \mu \mathrm{mol} / \mathrm{min}$ under the specified conditions of assay.

\section{Results}

As shown in table 1, the activity of 3-phosphoglycerate dehydrogenase was considerably reduced in the fibroblasts of both patients ( $22 \%$ and $13 \%$, respectively, of the mean control value) whereas the other enzymatic activities of the serine pathway were normal. Figure 2 illustrates the effect of 3-phosphohydroxypyruvate concentration on the activity of the enzyme from case 1 and from a control. The enzyme was markedly inhibited by raised concentrations of 3-phosphohydroxypyruvate. $\mathrm{KCl}$ released the inhibition and displaced the optimal concentration of substrate from $10 \mu \mathrm{M}$ at 100 $\mathrm{mM} \mathrm{KCl}$ to $50 \mu \mathrm{M}$ at $400 \mathrm{mM} \mathrm{KCl}$. This salt effect is analogous to the one described for $\mathrm{D}$-glycerate dehydrogenase, whose inhibition by hydroxypyruvate is released by salt. ${ }^{11}$ The kinetic behaviour of the patient's enzyme was similar to that of the control except that $\mathrm{V}_{\max }$ was considerably reduced. The activity of 3-phosphoglycerate dehydrogenase was also measured in the physiological direction, by the reduction of $\mathrm{NAD}^{+}$in the presence of 3-phosphoglycerate as described by Willis and Sallach. ${ }^{9}$ The activity in fibroblasts of two controls was 0.3 and $0.5 \mathrm{mU} / \mathrm{mg}$ protein and undetectable ( $<0.1 \mathrm{mU} / \mathrm{mg}$ protein) in both patients.

\section{Discussion}

The two brothers presented in this report have a decreased level of serine and of glycine in the cerebrospinal fluid and to some extent also in the blood, associated with a similar, severe neurological syndrome. Whether the cataracts present in one of them are part of the disease remains unknown until more patients have been detected. As mentioned in the introduction, serine can be synthesised from glycolytic intermediates and can be converted to glycine in a reaction that generates methylenetetrahydrofolate $\left(\mathrm{N}_{5} \mathrm{~N}_{10}\right)$. Reciprocally, serine can be formed from two molecules of glycine through the action of serine hydroxymethyltransferase and the glycine cleavage system. The fact that both serine and glycine were decreased in cerebrospinal fluid of the two patients indicated that the defect occurred in the serine de novo biosynthetic pathway. This was confirmed by finding, in fibroblasts of the two patients, a markedly decreased activity of phosphoglycerate dehydrogenase, the first step in this pathway (fig 1).

Thus this disease has to be classified among the small number of 'anabolic' aminoacidopathies as the large majority of amino acid disorders are due to catabolic defects. ${ }^{12}$ Other synthesis defects are the urea cycle disorders proximal to arginase, homocystinaemia, and phenylketonuria causing a deficient synthesis of arginine, cysteine, and tyrosine respectively. The pathogenesis of these diseases is for the greater part determined by an accumulation of substrate(s) (ammonia and urea cycle intermediates, homocysteine, and phenylalanine, respectively). In the present disorder, it is unlikely that 3-phosphoglycerate dehydrogenase results in significant accumulation of 3-phosphoglycerate, as this metabolite can be readily utilised by glycolysis. Therefore, the deficiency of brain serine seems to be the main determinant of disease. Serine has a major role in a number of different biosynthetic reactions particularly in the synthesis of such important brain constituents as proteins, glycine, cysteine, serine phospholipids, sphingomyelins, and cerebrosides. The fact that treatment by serine caused some improvement in the symptomatology strongly indicates that the serine deficiency is at least partly responsible for the clinical picture in these patients.

Different explanations can be provided for the fact that there is still a residual 3-phosphoglycerate dehydrogenase activity of about $20 \%$ with apparently normal kinetic properties. A first possibility is that the mutation present in the patients caused a decreased expression of an intact protein, either due to a decreased transcription or to an increased mRNA instability. A second possibility is that it resulted in the formation of a protein with decreased stability or with decreased $V_{\max }$ or even in a totally inactive enzyme. In the latter case the

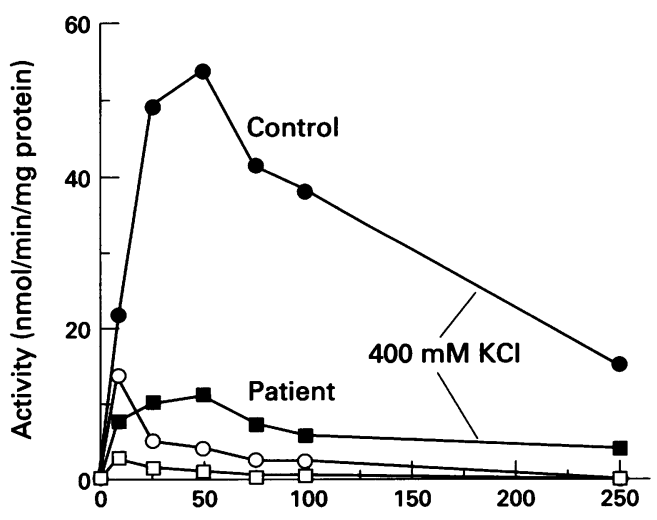

3-P-hydroxypruvate concentration $(\mu \mathrm{M})$

Figure 2 Effect of 3-phosphohydroxypyruvate and $\mathrm{KCl}$ concentrations (open symbols $100 \mathrm{mM}$, closed symbols 400 $m M$ ) on the activity of 3-phosphoglycerate dehydrogenase in extracts of fibroblasts of control (circles) and of patient (case 1, squares). 
residual activity would have to be explained by the presence of a different isozyme; it would therefore be of interest to determine the distribution of isozymic forms in different tissues to know which ones would be most affected by the mutation. If the deficient enzyme is the only one to be expressed in brain, this organ would then be largely dependent on the serine supply from the blood. It has been stated that brain is dependent upon its own L-serine biosynthesis, because there is a limited transport of L-serine through the blood-brain barrier due to competition with several other amino acids at the level of the neutral amino acid carrier. ${ }^{13-15}$

This report is the first one concerning an enzyme defect of the serine biosynthesis pathway. The reason why such deficiency has not been observed previously could be that plasma amino acid analysis is still often done by thin layer chromatography which is not able to detect moderate decreases. On the other hand, quantitative amino acid analysis should be performed at least also in the fasting state; a normal plasma serine concentration was found in case 2 two hours after a normal protein feeding. Furthermore, urinary amino acid analysis is totally unreliable for the detection of this disease as urinary serine concentrations are normally very low. Finally it is likely that the contribution of alimentary serine is less important to cerebrospinal fluid than to serum serine concentrations. Therefore, this report is a plea for more systematic amino acid analysis of cerebrospinal fluid in patients with unexplained neurological symptoms especially congenital microcephaly with severe encephalopathy. ${ }^{16}{ }^{17}$ This investigation is an important tool in the diagnosis of neurometabolic disorders ${ }^{18}$ and may possibly reveal other defects in the biosynthesis of amino acids.
We would like to thank Mrs G Berghenouse for competent technical help. This work was supported by the National Fund for Scientific Research (grants 3.0115.94 and 3.4596.92), by the Actions de Recherce Concertées, and by the Belgian Federal Service for Scientific, Technical and Cultural Affairs. EVS is Directeur de Recherche of the National Fund for Scientific Research. 1 Snell K. Enzymes of serine metabolism in normal, developing and

2 Barrett AJ. Proteolytic enzymes: serine and cysteine peptidases. Methods Enzymol 1994; 244: 1-460.

3 Snell $\mathrm{K}$. The duality of pathways for serine biosynthesis is a fallacy. Trends Biochem Sci 1986; 11: 241-3.

4 Knox WE, Herzfeld A, Hudson J. Phosphoserine phosphatase distribution in normal and neoplastic rat tissues. Arch Biochem Biophys 1969; 132: 397-403.

5 Snell K. Enzymes of serine metabolism in normal and neoplastic rat tissues. Biochim Biophys Acta 1985;843: 276-81.

plastic rat tissues. Biochim Biophys Acta 1985; 843: 276-81. in rat hepatomas. Biochem $\mathcal{F} 1986 ; 233: 617-20$.

7 Snell K, Natsumeda Y, Eble JN, Glover JL, Weber G. Enzymic imbalance in serine metabolism in human colon carcinoma and rat sarcoma. $B r \mathcal{F}$ Cancer 1988; 57: 87-90.

8 Bridgers WF. Mouse brain phosphoserine, phosphohydrolase and phosphotransferase. $\mathcal{F}$ Biol Chem 1967; 242: 2080-5.

9 Willis JE, Sallach HJ. The occurrence of D-3-phosphoglycerate dehydrogenase in animal tissues. Biochim Biophys Acta 1964; 81: 39-54.

10 Dawkins PD, Dickens F. The oxidation of D- and L-glycerate by rat liver. Biochem $\mathcal{f}$ 1965; 94: 353-67.

11 Sugimoto E, Kitagawa Y, Hirose M, Chiba H. Mechanisms of inhibition and activation of beef liver D-glycerate dehydrogenase by inorganic anions. $\mathcal{F}$ Biochem 1972; 72: 1317 25.

12 Scriver CR, Beaudet AL, Sly WS, Valle D. Amino acids. In: Scriver CR, Beaudet AL, Sly WS, Valle D, eds. The metabolic and molecular bases of inherited disease. New York: McGraw-Hill, 1995:1015-368.

13 Felig P, Wahren J, Ahlborg G. Uptake of individual amino acids by the human brain. Proc Soc Exp Biol Med 1973; 142: $230-1$.

14 Oldendorf WH, Szabo J. Amino acid assignment to one of three blood-brain barrier amino acid carriers. Am $¥$ Physiol 1976; 230: 94-8.

15 Smith QR, Momma S, Aoyagi M, Rapoport SI. Kinetics of neutral amino acid transport across the blood-brain barrier. F Neurochem 1987; 49: 1651-8.

16 Scheffer IE, Baraitser M, Wilson J, Godfrey C, Brett EM Autosomal recessive microcephaly with severe psychomotor retardation. Neuropediatrics 1992; 23: 53-6.

17 Gross-Tsur V, Joseph A, Blinder G, Amir N. Familial microcephaly with severe neurological deficits: a description of five affected siblings. Clin Genet 1995; 47: 33-7.

18 Jaeken J. Cerebrospinal fluid as a tool in the diagnosis of neurometabolic diseases: amino acid analysis before and after acid hydrolysis. Eur $\mathcal{f}$ Pediatr 1994;153 (suppl 1):S86-9. 